\title{
輸血関連急性肺障害
}

\author{
岡崎仁 \\ 日本赤十字社血液事業本部中央血液研究所
}

(平成 17 年 12 月 12 日受付)

(平成 17 年 12 月 20 日受理)

\section{TRANSFUSION-RELATED ACUTE LUNG INJURY}

\author{
Hitoshi Okazaki
}

Japanese Red Cross Society, Blood Service Headquarters, Central Blood Institute

\begin{abstract}
Key words : non-hemolytic transfusion reaction, acute lung injury, diagnostic criteria
\end{abstract}
\section{はじめに}

新たな技術の導入やより安全な献血者の確保な どの方策により輸血によるウイルス感染などの危 険性が少なくなり, 輸血用血液の安全性は高く なってきている. しかし, いわゆる非感染性非溶 血性輸血副作用の機序の解明, 予防策については 特殊な場合を除いて未解決な部分が多い. 日本赤 十字社の調查によると副作用報告年間約 2,000 件 の中で非溶血性副作用の占める割合は約 8 割にの ほるが，はっきりとした原因がつかめているもの はほんの一握りでしかない.一般に蔚麻疹などの アレルギー性の副作用と呼ばれているものの多く は原因が明らかになっていない.

その中で重篤なものの一つとして即時型の副作 用であるアナフィラキシーがあるが, 輸血がはじ まって短時間でおこることもあり，医療関係者の 認識度も高い。この中には, 受血者のハプトグロ ビンや IgA な゙血清蛋白質の欠損が原因と突き 止められたものもある ${ }^{1}$.

最近注目されてきているもう一つの重篤な非溶 血性輸血副作用である輸血関連急性肺障害は, そ の発症が即時型のアレルギー性の副作用よりもや やおくれて発症することや，その副作用に対する 認識が医療関係者にそしいことから，これまであ
まり重要視されていなかった.しかし，この副作 用は実はかなり以前より症例報告があり, 少なく とも文献上は 1950 年代より報告がなされている. 文献上はHypersensitivity reactions ${ }^{2)}$, Pulmonary edema in the course of a blood transfusion $^{3)}$, Pulmonary infiltrates associated with leukoagglutinin transfusion reactions ${ }^{4}$, Pulmonary hypersensitivity reactions ${ }^{5) \sim 8)}$, Severe allergic pulmonary oedema ${ }^{9)}$, Transfusion reaction with pulmonary infiltration ${ }^{10)}$ な゙様々な呼称で報告例 が散見され，その発症機序に抗白血球抗体が関与 していることが推定されていた. その後まとまっ た形での報告が 1985 年 Popovsky らによりなさ れ, Transfusion-related acute lung injury (TRALI) との呼称により独立した一つの副作用 の病態として認識されるようになった ${ }^{11)}$. 本稿で はこの TRALIについて概説する.

\section{TRALI の症状，鑑別診断}

典型的症状および臨床所見としては急性の呼吸 困難, 重篤な低酸素血症, 胸部レントゲン上の肺 水腫所見, 発熱, 血圧低下 (時に上昇) その他に も咳嗽, 喀痰, 抻管チューブからの泡沫状喀痰, 多呼吸, 頻脈, チアノーゼ, 胸部聴診上湿性ラ音 などがある. 経時的に詳しく調べると一過性の白 
血球減少がおこっていることも最近報告されてい $る^{12) 13)}$. これらの症状は輸血後数時間以内に発生 し，一般的には一過性であり，早期発見と適切な 酸素療法, 呼吸補助療法により回復することが多 いとされている．輸血に伴って呼吸困難を呈する 他の病態との鑑別も重要であり, 輸血関連循環過 負 荷 (Transfusion Associated Circulatory Overload, TACO)を含めた心不全, アナフィラキシー ショック,污染された血液製剤による細菌感染(敗 血症）などを念頭におき鑑別診断をしなければな らない"14) 17).

\section{TRALI の発生頻度}

TRALI の発症頻度は輸血血液 1 単位あたり 0.014\% から $0.08 \%$, 輸血される患者あたり $0.04 \%$ から $0.16 \%$ といわれており, 死亡率は約 $10 \%$ と されている ${ }^{18)}$.しかし TRALI の診断基準が報告 により異なっているために正確な頻度については はっきりとしない.さらに TRALI が臨床の現場 ではっきりと認識されているかどうかも問題では ある。

各国の報告を見ると，副作用の報告体制の違い によりさまざまではあるが，米国では 2001 年〜 2003 年の 3 年間における輸血関連死亡のなかで TRALI は一番の原因となっている. 米国FDA への報告は輸血関連死亡の場合のみであり,

TRALI の発生頻度や死亡率に関するデー夕はな いが, 3 年間での TRALIによる死亡例は 49 例で, TRALI の致死率から考えても死亡に至らない TRALI 症例はかなりの数に上ると推定され る ${ }^{19)}$. 英国では最新の SHOT (Serious Hazards of Transfusion) の報告によると 2004 年には 23 例の TRALI が報告され, 17 例が possible 以上とされ, うち 3 例が死亡している ${ }^{20)}$. フランスでは 2003 年には 15 例の TRALI 報告例のうち 3 例が死亡 している ${ }^{21)}$. 日本においては日赤への副作用自発 報告に基づく統計で, TRALIが疑われる症例は 1997 年よりこの病態が臨床的に認識されるよう になるとともに増えてきており，最近では年間約 30 例程度の報告がある. あとに述べる新たな診断 基準を適用しこれまでの症例を再評価したとこ ろ, 1997 年から 2004 年までに TRALI が 99 例, possible TRALI が 27 例診断され，死亡率は 10 数\%である. ドナーの検体を調べて TRALI の症 例とその他の副作用の症例を比較検討してみる と, TRALIを起こした症例の原因となったドナー には半数に抗白血球抗体が認められるが, 他の副 作用を起こしたドナーでは 10 数\%であり, 有意差 が認められた．患者の側の抗白血球抗体の頻度は TRALI の症例と他の副作用の症例とで差は認め られていないので, 患者の抗白血球抗体の TRALI への関与についてははっきりとしたことは現時点 では不明であるが, 保存前白除により TRALIの 頻度が減少したとの報告もあり, 関与は否定でき ない222.

\section{TRALI の原因製剤}

血漿を含んだすべての製剤で起こるとされてお り, 全血製剂, 赤血球製剤, 新鮮凍結血槳, 血小 板製剂でおこることが多いとされているが, 免疫 グロブリン ${ }^{2324)}$ やクリオプレシピテート ${ }^{25)}$ でおこ ることも報告されている。顆粒球輸血でおこった TRALI の報告もある ${ }^{2627)}$.

\section{TRALIを起こした患者の原疾患}

TRALI のリスクは輸血を必要とする疾患すべ てにあるのだが，なかでも特殊な病態について言 及している報告が散見される，心蔵手術の患 者 ${ }^{28)}$, 骨髄移植後の患者 ${ }^{29)}$ - 31), 肝臓移植後の患 者 ${ }^{32)}$, 一度 TRALI を起こした患者にもう一度お こる例吕などがある.

\section{TRALI の病因}

TRALIについては現在まで二つの異なった病 因が提唱されている.

一つは免疫学的機序によるもので, もう一つは 非免疫学的機序によるものである.

免疫学的機序によるものは何らかの抗原抗体反 応が肺障害を引き起こしているという仮説であ る. ドナー由来の抗白血球抗体もしくは患者がも ともと持っている抗白血球抗体が原因となり, そ れぞれ，患者白血球もしくは製剤中に残存してい る白血球との相互作用により, 白血球の活性化が 起こり, 補体の活性化, 肺毛細血管への付着およ びその傷害, 血管透過性の充進などを惹起し, 非 心原性の肺水腫を起こすという説（抗体説）であ 
る.

Popovskyらは1985年に 36 例の TRALIを報 告しているが,そのうち $89 \%$ においてドナーに抗 白血球抗体を見いだしている ${ }^{11)}$. 抗好中球抗体と 抗 HLA class I 抗体が原因として提唱されたが, すべてのケースで特異性が一致したわけではな かった．抗 HLA class I 抗体の関与する TRALI 症例については 1970 年頃より報告があり ${ }^{34) ~ 36), ~}$ 抗好中球抗体に関しても今までに抗 HNA-1a (NA-1), HNA-1b(NA-2), HNA-2a(NB-1), NB-2, HNA-3a（5b）抗体による TRALI が報告されてい $ろ^{1729937) 399} .1999$ 年に Kopko らは抗 HLA class II 抗体による TRALI の発症を報告し，その後相次 いで抗 HLA class II 抗体による TRALI の報告が なされている ${ }^{36 / 40) \sim 44)}$. 患者側に抗体が見いだされ た TRALIのケースも報告されている826)3134). さ らに単球 (Monocyte) に対する抗体も TRALI 症例で見いだされている(5) 47). また抗 IgA 抗体 の関与も報告されている ${ }^{48}$. 片肺移植 10 週後の 患者で抗 HLA-B44 抗体陽性の血液を輸血され, HLA class I（B44）が一致した移植肺のみに TRALI を発症したという報告もあり,血球系以外 の細胞と抗体の反応でも TRALI が起こる可能性 を示唆している ${ }^{49)}$. また，二人以上のドナーから の輸血を受けた患者がドナーの血液間の抗原抗体 反応による免疫複合体の形成により TRALIを起 こした可能性がある例も報告されている275051). このように免疫学的機序にも様々な抗原抗体反応 が関わっていると推定され，未だ認識されていな い抗体が誘因となっている可能性もある. Grimminger らの報告では抗 $5 b$ 抗体（抗 HNA-3a 抗 体）を用い，顆粒球と肺動脈血管内皮細胞との共 培養で Leukotriene C4 など血管透過性を立進す る物質が放出されることを見いだしている た, Nishimura らは抗 HLA-class II 抗体と可溶性 HLA 抗原により形成される immune complex が 顆粒球と肺毛細血管内皮細胞との共培養で内皮細 胞の傷害を起こすことを示している ${ }^{53)}$. さらに Kopko らは抗 $5 \mathrm{~b}$ 抗体が顆粒球の priming に関与 していることを示している(4). このようにいくつ かの知見が得られているが, 発症の詳細な機序に
関してはっきりとした答えは出ていない。

発症がまれであることより，前向きの研究はな かなか困難であるが, 2001 年に Palfi らによる初 めての prospective randomized controlled trial の 報告がなされた. 105 人の ICU 患者を対象とし， 2 ユニット以上の FFP を必要とする患者に, 3 回 以上の経産婦のドナーからの FFP とコントロー ルの FFP をそれぞれ 4 時間の間隔をあけ投与し た. 半数では最初にコントロールの FFP, もう半 数では最初に経産婦からの FFP を投与し, 心拍, 体温, 血圧, P/F ratio を指標とし評価したところ, 5 人に輸血副作用がみられそのうち 4 人は経産婦 がドナーの FFPを輸血された後だった. 1 人の患 者で TRALI が発症し，このケースも経産婦から の FFP の投与後であり, 抗好中球抗体が陽性で あった. 統計的には $\mathrm{P} / \mathrm{F}$ ratioにおいて, 経産婦か らの FFP 投与後がコントロールの FFP 投与後よ り有意に低下していた ${ }^{55}$. 経産婦由来の血液中の 抗 HLA 抗体に関しては妊娠回数に伴って高くな る傾向があることが報告されており，実際に，予 防策を講じている血液センターの例も報告されて いる ${ }^{5657)}$.

前向き研究以外では TRALI の原因となったと 考えられるドナーの血液による過去の副作用歴を 追跡する look-back studyが行われている. TRALI 発症例でのドナーが抗 HLA class I 抗体, 抗 HLA class II 抗体, 抗好中球抗体を保有してい た場合の, そのドナーの過去の副作用への関与の 履歴を調べており, TRALI 発症が確認されたとい う報告もあれば，確認できなかったという報告も

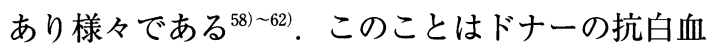
球抗体の存在が TRALI 発症の十分条件ではない ことを示唆している.

免疫学的機序による動物モデルも作成されてお り, Seeger らによる ex vivoの rabbit lung を用い た抗 $5 b$ 抗体（抗 HNA-3a 抗体）と $5 b$ 陽性の白血 球を用いた系では rabbit plasma の存在下に肺水 腫モデルを作成している ${ }^{63)}$. またBuxらは rat lung 用い, mouse monoclonal 抗 HNA-2a 抗体 と HNA-2a 陽性率 70\% 以上の白血球を灌流する ことにより肺水腫を生じさせている ${ }^{64)}$. Susskind 
らは BALB/c mouse を用い, mouse MHC class I mAb の injection により TRALI 様の病態を生じ させている ${ }^{65)}$.

ヒトでの TRALIを目的とした検討ではない が，新生児の溶血性疾患の治療のために有用と思 われている抗 HLA 抗体, 抗単球抗体を健常者に 投与し，その効果をみる実験で予期しなかった副 作用として TRALI が発症した事例が報告されて いる.これは抗体だけで健常者にも TRALIが発 症することを示唆しており，抗体説を支持するも のと考えられる ${ }^{45}$ 46).

また母子間での輸血により TRALI を発症する 事例も報告されており，子供の白血球により母親 が感作され，抗体を作ってしまっている例もあり， 母子間の輸血のリスクの一つに TRALI があげら れている66) 68).

非免疫学的機序によるものは, Silliman らのグ ループにより主に提唱されているのだが, TRALI 症例の病因として, 患者の状態(例えば, 感染症, 直近の手術, サイトカインの投与, 大量の輸血, 炎症など）と，製剤の中に蓄積される活性脂質の 存在が重要であるという説である ${ }^{69)}$.この仮説の 動物モデルとしては, 保存された赤血球または血 小板製剂をLPS 投与後に ratの肺に灌流すると 肺障害が起きるというものである. 保存された血 液製剤中の lysophosphatidylcholine (lyso-PC)が, 活性物質であるとされている(7071).

In vitroのモデルでは, 肺毛細血管内皮細胞を 用いた好中球との共培養実験系で，肺血管の障害 には LPS と lyso-PCによる好中球の活性化と, 肺 血管内皮細胞の活性化が関与するとしている ${ }^{72}$.

非免疫学的機序を支持する根拠としては, Silliman らの 90 例の TRALI についての報告がある. 4 年間に一つの病院で 90 例の TRALI 症例を集積 しており，その頻度は $1: 1,120$ であった．抗白血 球抗体検出率は $25 \%$ であり, 特異性が確認できた のは $3.6 \%$ にすぎなかった に $^{73)}$.

この非免疫学的機序に関する反論的論文も最近 発表されている ${ }^{74)}$.

\section{TRALI $の$ 病理}

Dry らが 1999 年に報告した TRALIの剖検例
は，肺水腫を起こして 2 時間で死亡しており，初 期の TRALI の肺病変をよくとらえていると考え られる ${ }^{75)}$. 一般に ALI/ARDSの病理像はDAD (Diffuse Alveolar Damage) とされているが, 治療 や人工呼吸器による肺障害も加わった病理所見と なり，特徽的な所見はえられないことが多いが, この報告では肺毛細血管に抗中球の集簇が見ら れ, 肺胞上皮細胞の傷害, 肺胞領域の浸出物の貯 留が見られている.

\section{TRALI の診断基準の必要性}

このような報告の他にも少数の症例報告はここ 最近になりかなり増えてきており認識はかなり高 まってきているが, 最近まで診断基準は統一され ておらず，個々の研究者によりその診断基準はま ちまちであり, 何が TRALI で何が TRALI ではな いのかを判断できず，同じ土俵の上に立って比較 検討することができないような状況であった。 そ のため 2004 年の 4 月に Consensus Conference が催され，TRALIの診断基準案を提唱し，2004 年の 12 月に診断基準の推奨案が Transfusion に 掲載された ${ }^{76)}$.この診断基準案は 1994 年に提唱 された The American-European Consensus Conference on ARDS の ALI/ARDS の診断基準に基 づいたものであり, 救急医学, 呼吸器学分野での 認識は非常に高いものである ${ }^{7778)}$. しかし, 明確な 検査上の判定基準を伴わず，臨床的な診断基準で あるために, 今後 TRALIの病態が解明されてい くにつれ若干の改訂が必要になってくる可能性は ある. 表 $1 ， 2$ にその診断基準案(原文および和訳) を提示する．この診断基準では TRALI（確診例） と possible TRALI (可能性例) を分けて診断する ことになっており, 輸血以外の ALI の危険因子が 患者側に存在する場合には, TRALI の可能性例と して, 確診例とは区別して解析するようにされて いる. 両側肺の浸潤影, 輸血後 6 時間以内の発症, 輸血以前の ALIの存在の排除が盛り込まれてい るため, 輸血以外の原因でおこる ALIについてか なり厳しく排除できるのではないかと期待され る. National Heart, Lung and Blood Institute Working Group on TRALI でも TRALI について 定義をしているがほほ同様である ${ }^{79)}$. 
表 1 Recommended criteria for TRALI and possible TRALI

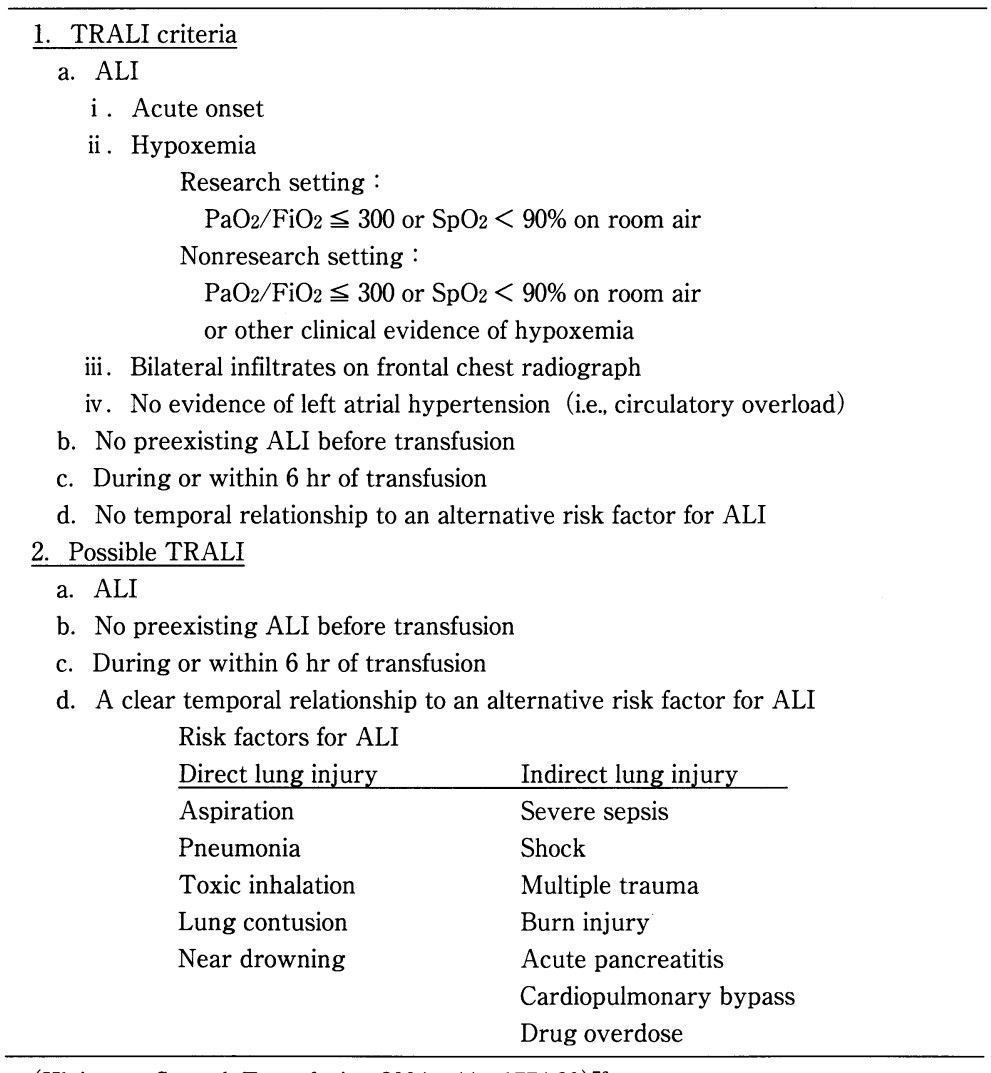

(Kleinman S, et al. Transfusion $2004 ; 44: 1774-89)^{76}$

鑑別診断のところでも述べたが，一番の問題と なるのは輸血による容量負荷をどのように評価す るかということである. TACO (Transfusion associated circulatory overload）は, TRALI と区別 するべき副作用の中でも重要なものである ${ }^{80)}$. 日 本において輸血による循環過負荷（容量負荷）を 輸血副作用であるとして正確な統計をとっていな かったため独自のデー夕はないが，最近報告され たカナダのケベック州のへモビジランスのデータ では TACO は 2000 年か 2003 年の 4 年間で 217 例報告され，TRALI の報告数 20 例と比較すると 約 10 倍の頻度でおきていることがわかる ${ }^{81)}$. TACO においても呼吸困難，肺水腫がおきるた め, TRALI との鑑別は重要である. 中心静脈圧や 肺動脈楔入圧を測定できるときはそれにより鑑別 を試みるが, すべての症例で測定できるわけでは
なく，その他の手段として BNP (B-natriuretic peptide）などの心不全で上昇するマーカーを使用 して鑑別をしようとする試みがなされている 肝移植後の患者で肺からの浸出物を採取し，鑑別 診断に役立てるなどの方法も試みられており，今 後さらに検討すべきと考えられる ${ }^{321}$.

\section{TRALI の診断基準の問題点}

新たに提唱された診断基準の問題点は，ALI/ ARDS の診断基準の問題点としてしばしばいわ れているようにマーカーとなるような検査値が示 されておらず，あくまで臨床的な診断であるとい うことである．もう一つは，片肺の患者に対する 取り扱いをどうするかも棚上げにされている. TRALI は全年齢層でおこるのだが, 診断基準を小 児にもそのまま適用して良いかどうかは，新生児 におこる場合も含め, 今後検討がさらに必要とな 
表 2 （和訳）TRALI と possible TRALI の診断指針の推奖案

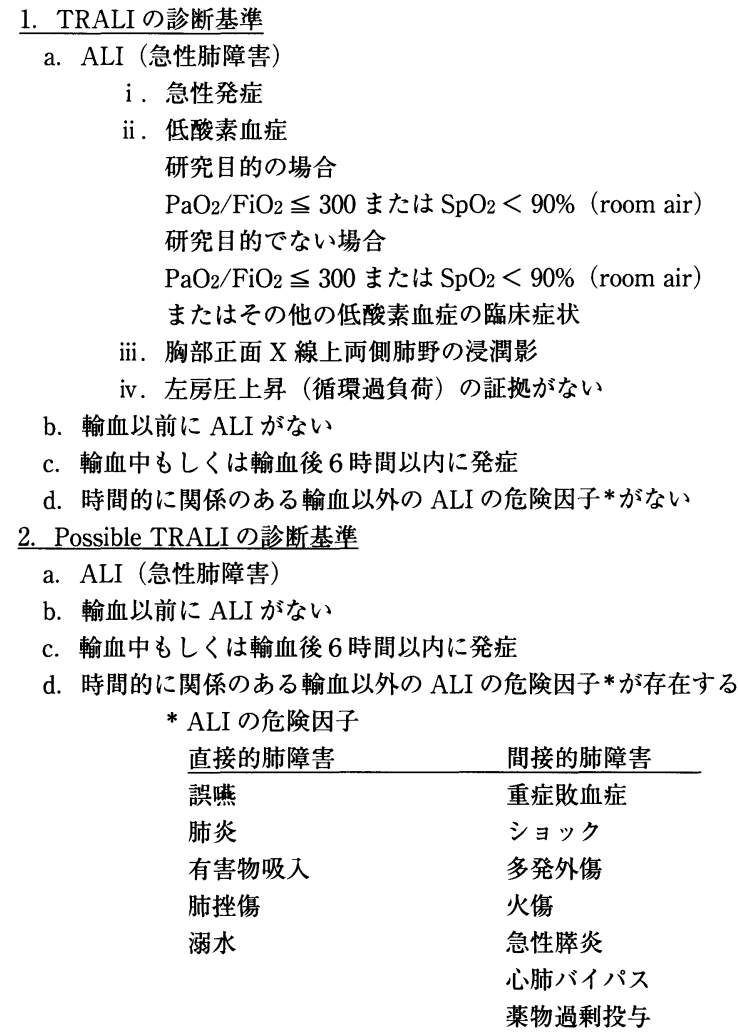

るかもしれない. 最近小児科領域での TRALIに ついて詳細な総説が出された ${ }^{83)}$. また, 除外基準 がないため, 心不全の証拠がはっきりしないよう な肺水腫症例, 明らかにアナフィラキシーである が肺浸潤影がレントゲン上両側に認められてしま うような症例を TRALI と診断してしまう危険性 がある.また，ALIではないがもとから肺に陰影 が存在したり，慢性の呼吸不全の状態であったり した症例で, 輸血により悪化したような場合 TRALI と診断できないことなどの問題点がある. これらの問題については今後, 確実な症例を積み 重ねていって新たな診断基準の作成を考えねばな らない.

\section{TRALI の予防策}

現時点で TRALIを確実に予防できる方法はな いが，少しでもリスクを少なくするため，血槳成 分を多く含む血液製剤からの女性献血者の排除な
どの提案がなされており，実際にそれを実行して いるところもある. 日本では一度 TRALI を起こ した抗白血球抗体陽性の献血者の血液は輸血には 用いないこととしている. 抗白血球抗体は一般に 経産婦で多く検出されるが, look-back study の結 果も示すようにTRALIを起こしたドナーの血液 で全例 TRALI を起こすわけではないこと，また すべての抗白血球抗体が危険であるという証拠が ないことを考えると, 現時点で特定の献血者だけ を排除することが, 効果的かどうかはドナープー ルの減少の問題も含めて慎重に対応しなければな らないであろう ${ }^{56 / 84)}$.

\section{TRALI の治療}

特異的な治療はなく Supportive care を基本と する. 酸素療法 $\left(\mathrm{PaO}_{2}>60\right.$ Torr, $\mathrm{SpO}_{2}>90 \%$ を保 つ）が必要になるが, 挿管および人工呼吸管理が 必要になることも多い。呼吸管理の方法は ARDS 
の呼吸管理に準ずる. PEEP, Small tidal volume, Permissive hypercapnia などの strategyを用い て呼吸管理を行う。症例報告ではあるが，体外膜 型人工肺により救命しえたという報告もあ

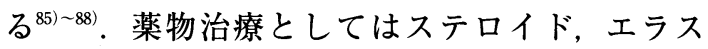
ターゼ阻害剤などが使用されることが多いが，有 効であるというはっきりとしたエビデンスは今の ところない．利尿剤はかえって病態を悪化させる 可能性があるため, 心不全との鑑別診断は重要に なる ${ }^{8990)}$. 最近日本呼吸器学会より ALI/ARDS 診療のためのガイドラインが刊行されたので参照

して頂きたい.

\section{おわりに}

以上 TRALI について概説したが，診断基準に 該当しないような軽症例の問題や, 非免疫学的機 序による TRALI のさらなる検証, 発症機序の解 明, 発症にかかわる危険因子の解明, 診断のため のマーカーの開発など，様々な問題が山積してお り, 今後のさらなる研究の発展および有効な予防 策の開発が望まれる.

\section{文献}

1) Shimada $E$, Tadokoro $K$, Watanabe $Y$, et al : Anaphylactic transfusion reactions in haptoglobindeficient patients with IgE and IgG haptoglobin antibodies. Transfusion, 42:766-773, 2002.

2) Barnard RD : Indiscriminate transfusion : a critique of case reports illustrating hypersensitivity reactions. N Y State J Med, $51: 2399-2402,1951$.

3) Philipps E, Fleischner FG : Pulomonary edema in the course of a blood transfusion without overloading the circulation. Dis Chest, $50: 619-623$, 1966.

4) Ward HN : Pulmonary infiltrates associated with leukoagglutinin transfusion reactions. Ann Intern Med, $73: 689-694,1970$.

5) Ward HN, Lipscomb TS, Cawley LP : Pulmonary hypersensitivity reaction after blood transfusion. Arch Intern Med, 122 : 362-366, 1968.

6) Pearlstein AT : Pulmonary hypersensitivity reaction during blood transfusion. N Y State J Med, $71: 2683$-2685, 1971.

7) Thompson JS, Severson CD, Parmely MJ, et al : Pulmonary "hypersensitivity" reactions induced by transfusion of non-HL-A leukoagglutinins. N Engl J Med, $284:$ 1120-1125, 1971.
8) Wolf CF, Canale VC : Fatal pulmonary hypersensitivity reaction to HL-A incompatible blood transfusion : report of a case and review of the literature. Transfusion, $16: 135-140,1976$.

9) Kernoff PB, Durrant IJ, Rizza CR, et al : Severe allergic pulmonary oedema after plasma transfusion. Br J Haematol, 23 : 777-781, 1972.

10) Andrews AT, Zmijewski CM, Bowman HS, et al : Transfusion reaction with pulmonary infiltration associated with HL-A-specific leukocyte antibodies. Am J Clin Pathol, 66 : 483-487, 1976.

11) Popovsky MA, Moore SB : Diagnostic and pathogenetic considerations in transfusion-related acute lung injury. Transfusion, $25: 573-577,1985$.

12) Nakagawa $M$, Toy $P$ : Acute and transient decrease in neutrophil count in transfusion-related acute lung injury : cases at one hospital. Transfusion, $44: 1689-1694,2004$.

13) Marques MB, Tuncer HH, Divers SG, et al : Acute transient leukopenia as a sign of TRALI. Am J Hematol, 80 : 90-91, 2005.

14) Popovsky MA, Audet AM, Andrzejewski C, Jr. : Transfusion-associated circulatory overload in orthopedic surgery patients : a multi-institutional study. Immunohematol, $12: 87-89,1996$.

15) Looney MR, Gropper MA, Matthay MA : Transfusion-related acute lung injury : a review. Chest, $126: 249-258,2004$.

16) Silliman CC, Ambruso DR, Boshkov LK : Transfusion-related acute lung injury. Blood, 105 : 2266-2273, 2005.

17) Webert KE, Blajchman MA : Transfusion-related acute lung injury. Transfus Med Rev, $17: 252-$ 262, 2003.

18) Webert KE, Blajchman MA : Transfusion-related acute lung injury. Curr Opin Hematol, $12: 480-$ 487, 2005.

19) Holness L : Transfusion Related Acute Lung Injury (TRALI) -The FDA Current View, Food and Drug Administration Blood Products Advisory Committee, 2004

20) SERIOUS HAZARDS OF TRANSFUSION-Annual Report 2004. the Serious Hazards of Transfusion Steering Group, Manchester, 2004

21) Rebibo D, Hauser L, Slimani A, et al : The French Haemovigilance System : organization and results for 2003. Transfus Apheresis Sci, $31: 145-$ 153, 2004.

22) Yazer MH, Podlosky L, Clarke G, et al : The effect of prestorage $\mathrm{WBC}$ reduction on the rates of febrile nonhemolytic transfusion reactions to platelet concentrates and RBC. Transfusion, 44 : 
$10-15,2004$.

23) Suassuna JH, da Costa MA, Faria RA, et al : Noncardiogenic pulmonary edema triggered by intravenous immunoglobulin in cancer-associated thrombotic thrombocytopenic purpura-hemolytic uremic syndrome. Nephron, 77 : 368-370, 1997.

24) Rizk A, Gorson KC, Kenney L, et al : Transfusion-related acute lung injury after the infusion of IVIG. Transfusion, $41: 264-268,2001$.

25) Reese EP, Jr., McCullough JJ, Craddock PR : An adverse pulmonary reaction to cryoprecipitate in a hemophiliac. Transfusion, $15: 583-588,1975$.

26) Sachs UJ, Bux J : TRALI after the transfusion of cross-match-positive granulocytes. Transfusion, $43: 1683-1686,2003$.

27) O'Connor JC, Strauss RG, Goeken NE, et al : A near-fatal reaction during granulocyte transfusion of a neonate. Transfusion, $28: 173-176$, 1988.

28) Culliford AT, Thomas S, Spencer FC : Fulminating noncardiogenic pulmonary edema. A newly recognized hazard during cardiac operations. J Thorac Cardiovasc Surg, 80 : 868-875, 1980.

29) Ganguly S, Carrum G, Nizzi F, et al : Transfusionrelated acute lung injury (TRALI) following allogeneic stem cell transplant for acute myeloid leukemia. Am J Hematol, 75 : 48-51, 2004.

30) Urahama N, Tanosaki R, Masahiro K, et al : TRALI after the infusion of marrow cells in a patient with acute lymphoblastic leukemia. Transfusion, $43:$ 1553-1557, 2003.

31) Leach M, Vora AJ, Jones DA, et al : Transfusionrelated acute lung injury (TRALI) following autologous stem cell transplant for relapsed acute myeloid leukaemia : a case report and review of the literature. Transfus Med, $8: 333-337,1998$.

32) Yost CS, Matthay MA, Gropper MA : Etiology of acute pulmonary edema during liver transplantation : a series of cases with analysis of the edema fluid. Chest, 119: 219-223, 2001.

33) Win N, Montgomery J, Sage D, et al : Recurrent transfusion-related acute lung injury. Transfusion, 41 : 1421-1425, 2001.

34) Bux J, Becker F, Seeger W, et al : Transfusionrelated acute lung injury due to HLA-A2-specific antibodies in recipient and NB1-specific antibodies in donor blood. Br J Haematol, $93: 707-713$, 1996.

35) Popovsky MA, Saidman SL : Case records of the Massachusetts General Hospital. Weekly clinicopathological exercises. Case 40-1998. A 49-yearold woman with thrombotic thrombocytopenic purpura and severe dyspnea during plasmapheresis and transfusion. N Engl J Med, 339 : 2005-2012, 1998.

36) Wallis JP, Lubenko A, Wells AW, et al : Single hospital experience of TRALI. Transfusion, 43 : 1053-1059, 2003.

37) Davoren A, Curtis BR, Shulman IA, et al : TRALI due to granulocyte-agglutinating human neutrophil antigen-3a (5b) alloantibodies in donor plasma : a report of 2 fatalities. Transfusion, 43 : 641-645, 2003.

38) Fung YL, Goodison KA, Wong JK, et al : Investigating transfusion-related acute lung injury (TRALI). Intern Med J, $33:$ 286-290, 2003.

39) Nordhagen R, Conradi M, Dromtorp SM : Pulmonary reaction associated with transfusion of plasma containing anti-5b. Vox Sang, $51: 102-$ 107, 1986.

40) Kopko PM, Mackenzie, M.R., Paglieroni, T.G. : Can HLA class II antibodies cause TRALI ? (abstract). Transfusion, 39 (Suppl) : 58S, 1999.

41) Kopko PM, Popovsky MA, MacKenzie MR, et al : HLA class II antibodies in transfusion-related acute lung injury. Transfusion, $41: 1244-1248$, 2001.

42) Varela M, Mas A, Nogues N, et al : TRALI associated with HLA class II antibodies. Transfusion, $42: 1102,2002$.

43) Kao GS, Wood IG, Dorfman DM, et al : Investigations into the role of anti-HLA class II antibodies in TRALI. Transfusion, $43:$ 185-191, 2003.

44) Win N, Brown C, Navarrete C : TRALI associated with HLA class II antibodies. Transfusion, $43: 545-546,2003$.

45) Flesch BK, Neppert J : Transfusion-related acute lung injury caused by human leucocyte antigen class II antibody. Br J Haematol, $116: 673-676$, 2002.

46) Dooren MC, Ouwehand WH, Verhoeven AJ, et al : Adult respiratory distress syndrome after experimental intravenous gamma-globulin concentrate and monocyte-reactive IgG antibodies. Lancet, 352 : 1601-1602, 1998.

47) Kopko PM, Paglieroni TG, Popovsky MA, et al : TRALI : correlation of antigen-antibody and monocyte activation in donor-recipient pairs. Transfusion, $43:$ 177-184, 2003.

48) Saigo K, Sugimoto $T$, Tone K, et al : Transfusionrelated acute lung injury in a patient with acute myelogenous leukaemia having anti-IgA2m (1) antibody. J Int Med Res, 27 : 96-100, 1999.

49) Dykes A, Smallwood D, Kotsimbos T, et al : 
Transfusion-related acute lung injury (Trali) in a patient with a single lung transplant. $\mathrm{Br} \mathrm{J}$ Haematol, $109: 674-676,2000$.

50) Lucas G, Rogers S, Evans R, et al : Transfusionrelated acute lung injury associated with interdonor incompatibility for the neutrophil-specific antigen HNA-1a. Vox Sang, 79 : 112-115, 2000.

51) Eastlund DT, McGrath PC, Burkart P : Platelet transfusion reaction associated with interdonor HLA incompatibility. Vox Sang, $55: 157-160$, 1988.

52) Grimminger F, Kreusler B, Schneider U, et al : Human leukoagglutinating antibody evokes cooperative leukotriene synthesis in pulmonary microvasculature. Model of transfusion-related acute lung injury. Circ Res, 68 : 503-512, 1991.

53) Nishimura $M$, Ishikawa $Y$, Satake $M$ : Activation of polymorphonuclear neutrophils by immune complex : possible involvement in development of transfusion-related acute lung injury. Transfus Med, 14 : 359-367, 2004.

54) Kopko PM : Merging the pathogenesis of transfusion related acute lung injury : the priming activity of the 5b (HNA-3) antibody. Transfusion, 44 (Suppl.) : 22A, 2004.

55) Palfi M, Berg S, Ernerudh J, et al : A randomized controlled trial oftransfusion-related acute lung injury : is plasma from multiparous blood donors dangerous? Transfusion, $41: 317-322,2001$.

56) Densmore TL, Goodnough LT, Ali S, et al : Prevalence of HLA sensitization in female apheresis donors. Transfusion, 39 : 103-106, 1999.

57) Insunza A, Romon I, Gonzalez-Ponte ML, et al : Implementation of a strategy to prevent TRALI in a regional blood centre. Transfus Med, 14 : 157-164, 2004.

58) Kopko PM, Marshall CS, MacKenzie MR, et al : Transfusion-related acute lung injury : report of a clinical look-back investigation. Jama, 287 : 1968-1971, 2002.

59) Win N, Ranasinghe E, Lucas G : Transfusion-related acute lung injury : a 5-year look-back study. Transfus Med, $12:$ 387-389, 2002.

60) Nicolle AL, Chapman CE, Carter V, et al : Transfusion-related acute lung injury caused by two donors with anti-human leucocyte antigen class II antibodies : a look-back investigation. Transfus Med, $14: 225-230,2004$.

61) Toy P, Hollis-Perry KM, Jun J, et al : Recipients of blood from a donor with multiple HLA antibodies : a lookback study of transfusion-related acute lung injury. Transfusion, 44 : 1683-1688, 2004.
62) Cooling $L$ : Transfusion-related acute lung injury. Jama, 288 : 315-316 ; author reply 316, 2002.

63) Seeger W, Schneider U, Kreusler B, et al : Reproduction of transfusion-related acute lung injury in an ex vivo lung model. Blood, $76: 1438-1444$, 1990.

64) Bux J, Hardt, O., Kohstall, M. Sibelius, U., Weissman, N. : Reproduction of granulocyte antibodymediated TRALI in an ex vivo rat lung model. Vox Sang, 87 (Suppl. 3) : S4, 2004.

65) Hicks WA, Susskind, B. : In vivo Murine Model of Transfusion-Related Acute Lung Injury. Transfusion, 44 (Suppl.) : 23A, 2004.

66) Goeken NE, Schulak JA, Nghiem DD, et al : Transfusion reactions in donor-specific blood transfusion patients resulting from transfused maternal antibody. Transplantation, $38: 306-$ 307, 1984.

67) Elbert C, Strauss RG, Barrett F, et al : Biological mothers may be dangerous blood donors for their neonates. Acta Haematol, 85 : 189-191, 1991.

68) Yang X, Ahmed S, Chandrasekaran V : Transfusion-related acute lung injury resulting from designated blood transfusion between mother and child : a report of two cases. Am J Clin Pathol, $121: 590-592,2004$.

69) Silliman CC, Paterson AJ, Dickey WO, et al : The association of biologically active lipids with the development of transfusion-related acute lung injury : a retrospective study. Transfusion, 37 : $719-726,1997$.

70) Silliman CC, Voelkel NF, Allard JD, et al : Plasma and lipids from stored packed red blood cells cause acute lung injury in an animal model. J Clin Invest, $101: 1458-1467,1998$.

71) Silliman CC, Bjornsen AJ, Wyman TH, et al : Plasma and lipids from stored platelets cause acute lung injury in an animal model. Transfusion, $43: 633-640,2003$.

72) Wyman TH, Bjornsen AJ, Elzi DJ, et al : A twoinsult in vitro model of PMN-mediated pulmonary endothelial damage : requirements for adherence and chemokine release. Am J Physiol Cell Physiol, 283 : C1592-1603, 2002.

73) Silliman CC, Boshkov LK, Mehdizadehkashi Z, et al : Transfusion-related acute lung injury : epidemiology and a prospective analysis of etiologic factors. Blood, 101 : 454-462, 2003.

74) Gajic O, Rana R, Mendez JL, et al : Acute lung injury after blood transfusion in mechanically ventilated patients. Transfusion, $44: 1468-1474$, 2004. 
75) Dry SM, Bechard KM, Milford EL, et al : The pathology of transfusion-related acute lung injury. Am J Clin Pathol, 112 : 216—221, 1999.

76) Kleinman $S$, Caulfield $T$, Chan $P$, et al : Toward an understanding of transfusion-related acute lung injury : statement of a consensus panel. Transfusion, $44:$ 1774-1789, 2004.

77) Goldman M, Webert KE, Arnold DM, et al : Proceedings of a consensus conference : towards an understanding of TRALI. Transfus Med Rev, $19: 2-31,2005$.

78) Bernard GR, Artigas A, Brigham KL, et al : The American-European Consensus Conference on ARDS. Definitions, mechanisms, relevant outcomes, and clinical trial coordination. Am J Respir Crit Care Med, 149 : 818-824, 1994.

79) Toy P, Popovsky MA, Abraham E, et al : Transfusion-related acute lung injury : definition and review. Crit Care Med, 33 : 721-726, 2005.

80) Popovsky MA : Transfusion and the lung : circulatory overload and acute lung injury. Vox Sang, 87 Suppl, $2: 62-65,2004$.

81) Robillard P, Nawej KI : Four-year cumulative incidence of serious adverse transfusion events in the Quebec hemovigilance system. Vox Sang, $89: 13,2005$.

82) Zhou L, Giacherio D, Cooling L, et al : Use of Bnatriuretic peptide as a diagnostic marker in the differential diagnosis of transfusion-associated circulatory overload. Transfusion, $45: 1056-1063$, 2005.

83) Sanchez R, Toy $P$ : Transfusion related acute lung injury: A pediatric perspective. Pediatr Blood Cancer, 2005.
84) Payne $\mathrm{R}$ : The development and persistence of leukoagglutinins in parous women. Blood, 19 : 411-424, 1962.

85) Nouraei SM, Wallis JP, Bolton D, et al : Management of transfusion-related acute lung injury with extracorporeal cardiopulmonary support in a four-year-old child. Br J Anaesth, 91 : 292-294, 2003.

86) Worsley MH, Sinclair CJ, Campanella C, et al : Non-cardiogenic pulmonary oedema after transfusion with granulocyte antibody containing blood : treatment with extracorporeal membrane oxygenation. Br J Anaesth, $67: 116-119$, 1991.

87) Yokota K, Fujii T, Kimura $K$, et al : Lifethreatening hypoxemic respiratory failure after repair of acute type a aortic dissection : successful treatment with venoarterial extracorporeal life support using a prosthetic graft attached to the right axillary artery. Anesth Analg, 92 : 872-876, 2001.

88) Lecamwasam HS, Katz D, Vlahakes GJ, et al : Cardiopulmonary bypass following severe transfusion-related acute lung injury. Anesthesiology, $97: 1311-1312,2002$.

89) Hashim SW, Kay HR, Hammond GL, et al : Noncardiogenic pulmonary edema after cardiopulmonary bypass. An anaphylactic reaction to fresh frozen plasma. Am J Surg, 147 : 560-564, 1984.

90) Levy GJ, Shabot MM, Hart ME, et al : Transfusion-associated noncardiogenic pulmonary edema. Report of a case and a warning regarding treatment. Transfusion, $26: 278-281,1986$. 